\title{
Spinal Cord Injuries in Taipei, Taiwan, 1978-1981
}

\author{
C. F. Chen, M.D. and I. N. Lien, M.D. \\ Department of Physical Medicine and Rehabilitation, National Taiwan University \\ Hospital, Taipei, Taiwan, R.O.C.
}

\begin{abstract}
Summary
This survey of spinal cord injuries in Taipei city from fanuary 1978 to December 1981 was carried out by a review of the hospital records. During these four years 560 patients with acute spinal cord injury (SCI) were admitted to the hospitals in the city of Taipei. Of these, 123 were inhabitants of Taipei city, showing the annual incidence of SCI in Taipei to be 14.6 per million population. As a result of injury 118 patients were paraparetic, 180 were paraplegic, 117 tetraparetic and 145 were tetraplegic. The average age was 36 years and 2 months and one third were in the 20 to 29 year age group. The male/female ratio was 4.9. The causes of SCI were traffic accidents $(44 \cdot 5 \%)$, accidental falls $(28.5 \%)$, struck by object $(14.6 \%)$ and sports injury $(3.4 \%)$. The mortality rate was $6.0 \%$. Respiratory complication was the leading cause of death, accounting for $58 \%$ of the total deaths.
\end{abstract}

Key words: Spinal cord injury; Incidence; Taipei.

\section{Introduction}

Spinal cord injury (SCI) is a serious traumatic condition, requiring a team of well trained specialists and a proper place for continuous management of these patients. In many countries spinal centres have been established for these purposes. Although there is no spinal centre in Taiwan the above mentioned team does exist in many general hospitals in Taipei and a few in Kaohsiung and Tainan (in southern Taiwan). Taipei, located in northern Taiwan, is the largest city in Taiwan. It is believed that, for the management of acute SCI, the inhabitants of northern, middle and eastern parts of Taiwan will usually be sent to the general hospitals in the city of Taipei; those in the southern part of Taiwan will be dealt with at Kaohsiung or Tainan. This study was carried out in the city of Taipei to discover the incidence of SCI in the city of Taipei and the gross pattern of SCI in Taiwan.

\section{Method}

This study was performed by a retrospective review of hospital records. All the 
general hospitals in the city of Taipei were surveyed and the records of patients admitted to these hospitals with acute spinal cord injury were studied for the four year period from January 1978 to December 1981. Confirmation of spinal cord injury included a detailed review of the hospital records coded with the following numbers of the International Classification of Disease (1969):

No. 806.0-9 fracture and fracture dislocation of vertebral column with spinal cord lesion.

No. 968.0-9 spinal cord lesion without evidence of spine injury.

After careful review each case was included in this study if the criteria met the classification requirements.

\section{Results}

\section{Incidence}

A total of 560 patients with acute SCI were identified. Of these 123 were inhabitants of Taipei city the population of the city of Taipei during that period being $2 \cdot 1$ million. Therefore the incidence of traumatic SCI of Taipei was $14 \cdot 6$ per million population per year. The other 437 patients, who were not inhabitants of the city of Taipei, were transferred from other parts of Taiwan to the hospitals in the city. Of those patients, $75 \%$ were admitted to the hospitals of Taipei city within 24 hours. It was noted that there was an increase in incidence from 1978 to 1980 , which in 1981 the numbers decreased.

\section{Age}

The age distribution is shown in Table I. There was a definite peak in the 20-29 year age group $(31.8 \%)$, followed by the 40-49 year group $(17.0 \%), 50-59$ year group $(15.9 \%)$ and finally the 30-39 year group $(15.4 \%)$. A high incidence of SCI $\left(64 \cdot 1^{\circ}\right)$ was present in the period from 20 to 49 years. The mean age of male patients was 36 years and 4 months while that of female patients was 33 years and 8 months.

Table 1 Age distribution of Spinal Cord Injury Patients

\begin{tabular}{lc}
\hline Age $(\mathrm{yr})$ & No. of Patients \\
\hline $0-9$ & $6\left(1 \cdot 1^{\circ}{ }_{0}{ }_{0}\right)$ \\
$10-19$ & $45\left(8 \cdot 0^{\circ}{ }_{0}\right)$ \\
$20-29$ & $178\left(31 \cdot 8^{\circ}{ }_{0}{ }_{0}\right)$ \\
$30-39$ & $86\left(15 \cdot 4^{\circ}{ }_{0}\right)$ \\
$40-49$ & $95\left(17 \cdot 0^{\circ}{ }_{0}{ }_{0}\right)$ \\
$50-59$ & $89\left(15 \cdot 9^{\circ}{ }_{0}\right)$ \\
$60-69$ & $40\left(7 \cdot 1^{\circ}{ }_{0}{ }_{0}\right)$ \\
$<70$ & $21\left(3 \cdot 8^{\circ}{ }_{0}\right)$ \\
\hline *20-49years: $359\left(64 \cdot 1^{\circ}{ }_{0}\right)$ average age $($ mean \\
+1 S.D. $):$ & male: $36 \cdot 3+15 \cdot 7$ \\
\multicolumn{2}{c}{ female: $33 \cdot 7+14 \cdot 2$}
\end{tabular}




\section{Causes of traumatic SCI}

Table 2 shows the causes of SCI. Traffic accidents being the most frequent cause, accounting for $44.5^{\circ}$ of all injuries. Eighty cases resulted from motorcycle collisions.

Table 2 Causes of Spinal Cord Injury

\begin{tabular}{lc}
\hline \multicolumn{1}{c}{ Cause } & No. of Patients \\
\hline Traffic accident & $249\left(44 \cdot 5^{\circ}{ }_{0}{ }^{\circ}\right)$ \\
Accidental fall & $157\left(28 \cdot 5^{\circ}{ }_{0}\right)$ \\
Struck by object & $82\left(14 \cdot 6^{\circ}{ }_{0}{ }_{0}\right)$ \\
Sports injury & $19\left(3 \cdot 4^{\circ}{ }_{0}\right)$ \\
Stab injury & $15\left(2 \cdot 7^{\circ}{ }^{\circ}\right)$ \\
Voluntary fall & $8\left(1.4^{\circ}{ }_{0}{ }_{0}\right)$ \\
Others & $30\left(5 \cdot 6^{\circ}{ }_{0}{ }_{0}\right)$ \\
\hline
\end{tabular}

The next most frequent causes of SCI were accidental falls $(28.5 \%)$ and struck by an object $(14.6 \%)$. The incidence of sports injuries was only $3.4{ }^{\circ}$, of whom 17 were caused when diving two when practicing judo.

In $15(2.7 \%)$ patients the SCI was caused by a stab injury. There were no instances of gunshot wounds in this study. Voluntary falls because of suicide attempts or during emergent conditions, such as escaping from a fire, resulted in eight spinal cord injuries.

\section{Sex distribution}

There were 465 males and 95 females, the male/female ratio being 4.9 (Table 3). The male/female ratio in every type of injury except for voluntary falls was in excess of one.

Table 3 Sex distribution and cause of Spinal Cord Injury

\begin{tabular}{lrcc}
\hline \multicolumn{1}{c}{ Cause } & Male & Female & $\mathrm{M} / \mathrm{F}$ \\
\hline Traffic accident & 216 & 33 & $6 \cdot 5$ \\
Accidental fall & 122 & 35 & 3.5 \\
Struck by object & 71 & 11 & $6 \cdot 5$ \\
Sports injury & 19 & 0 & - \\
Stab injury & 13 & 2 & $6 \cdot 5$ \\
Voluntary fall & 3 & 5 & $0 \cdot 6$ \\
Others & 21 & 9 & - \\
Total & 465 & 95 & 4.9 \\
\hline
\end{tabular}

\section{Neurological deficits}

Table 4 shows the relationship between the cause of trauma and the neurological deficit. Both traffic accidents and accidental falls caused mainly a cervical cord injury. There is also a higher incidence of complete cord damage from these 
Table 4 Causes of Spinal Cord Injury related to neurological deficits

\begin{tabular}{|c|c|c|c|c|}
\hline \multirow[t]{2}{*}{ Cause } & \multicolumn{2}{|c|}{ Paraplegia } & \multicolumn{2}{|c|}{ Tetraplegia } \\
\hline & $I^{\star}$ & $C^{\star \star}$ & $\mathrm{I}^{\star}$ & $C^{\star \star}$ \\
\hline Traffic accident & 47 & 69 & 58 & 75 \\
\hline Accidental fall & 35 & 53 & 29 & 40 \\
\hline Struck by object & 18 & 43 & 10 & 11 \\
\hline Sports injury & 0 & 0 & 8 & 11 \\
\hline Stab injury & 6 & 6 & 2 & 1 \\
\hline Voluntary fall & 2 & 6 & 0 & 0 \\
\hline Others & 10 & 3 & 10 & 7 \\
\hline Total (case no) & 118 & 180 & 117 & 145 \\
\hline$\left(\begin{array}{l}0 \\
0\end{array}\right)$ & $21 \cdot 1$ & $32 \cdot 1$ & $20 \cdot 9$ & $25 \cdot 9$ \\
\hline
\end{tabular}

two causes. Being struck by an object, stab injuries and voluntary falls more often caused paraplegia than tetraplegia. All sports injuries caused a cervical cord lesion. Overall, there were 298 cases $(53 \cdot 2 \%)$ with cord injury at or below the thoracic level, and 262 cases $(46 \cdot 8 \%)$ with a cervical cord injury. Complete cord damage was predominant in all injuries except stab injuries. About half the cases $\left(58^{\circ}{ }_{0}\right)$ were victims of complete cord injuries.

\section{Duration of hospitalisation}

The duration of hospitalisation varied proportionally with the severity and level of the cord lesion. The average stay in hospital was 44 days for those who were paraparetic, 81 days for paraplegics, 90 days for tetrapareties and 100 days for tetraplegics patients.

\section{Causes of death}

Thirty one patients died in hospital, the mortality rate being $6.0 \%$. Respiratory failure was the leading cause of death (Table 5), but it only occurred in tetraplegics. Sepsis due to infection from sores, renal failure and other associated lesions such as rupture of visceral organs or head injury were the other causes of death. Complete cord damaged patients had a higher risk of death that patients with incomplete cord damage.

Table 5 Causes of death in Spinal Cord Injury Patients

\begin{tabular}{lcccc}
\hline Cause of death & Paraparesis & Paraplegia & Tetraparesis & Tetraplegia \\
\hline Respiratory failure & 0 & 0 & 0 & 18 \\
Pressure sore & 0 & 3 & 0 & 1 \\
Renal failure & 0 & 1 & 0 & 0 \\
Others $\star \star$ & 2 & 3 & 0 & 3 \\
Total & 2 & 7 & 0 & 22 \\
\hline
\end{tabular}

$\star$ Mortality rate: $6 \cdot 0^{\circ}{ }_{0}$.

${ }^{\star \star}$ Head Injury, Visceral Rupture, GI Bleeding or Haemorrhagic Shock. 


\section{Discussion}

This survey revealed that the annual incidence of SCI in the city of Taipei was 14.6 per million population, this figure being within the range of the 11.5 to 23 new cases hospitalised per million population reported by Kraus (1980) in his review of the medical literature published from 1960 to 1978 . The reasons put forward for this variation of the reported incidences are the different methods of survey and the different socio-economic situations in each country. In the present series patients who died on arrival or at the place of accident were excluded. Therefore, the 14.6 rate may be an underestimate. The occurrence of SCI during each year showed a steady increase in case number from 1978 to 1980 and decreased in 1981. To ascertain whether the decrease of SCI in 1981 in Taipei is of any significance further investigation of SCI in the years following 1981 is indicated.

The age distribution of SCI in this survey is comparable with those of other surveys (Minaire, 1978; Gjone, 1979 and Fine, 1980). There were few cases in the age groups below 19 or beyond 60 . It is very easy to understand this pattern, since people with these ages in Taiwan have less chance of being exposed to dangerous situations. Those within the age range of 20 to 29 years have the highest incidence of SCI, partly due to their lack of experience in working, recreation or driving and their inadequate capacity to handle emergency situations.

Traffic accidents were the leading causes of SCI in Taiwan (Table 2), this being similar to what is found in western countries.

Only 2.7 per cent SCI were caused by a sports injury, and none resulted from a gunshot injury. The incidence of sports injury is much lower than those of Girard (1983) in France, Kraus (1975) for Northern California, and Fine (1980) for Alabama in the U.S.A., Minaire (1978) for Rhône area of France, Frankel (1969) for England, and Kuhn (1980) for Switzerland. The popular sports in Taiwan are baseball, basketball, tennis, table tennis, jogging and swimming. Except for swimming these sports do not carry a high risk of SCI. Very few people participate in high risk sports, such as rugby football, skiing, parachuting, trampoline gymnastics and car (or horse) racing. Therefore the incidence of sports injury in this survey is very low.

Kuhn (1983) reviewed the male/female ratio of SCI in various countries and stated that the ratio varies greatly between various countries because of their different socio-economic and cultural backgrounds. It ranged from 2.59 in Basle, Switzerland to 9.64 in Japan. Although there is a great variation between countries, 50 per cent of the reported ratios are in the range between 3.5 to $5 \cdot 0$. This study also revealed a ratio within these figures.

The male patients were predominant in all causes of SCI except in the category of voluntary falls. This particular sex distribution of voluntary jumpers has been mentioned by Girard $(1980 ; 1983)$ and Kuhn (1983). It is obvious that females prefer jumping from heights as their method of committing suicide.

As is shown in Table 4, traffic accidents, accidental falls and being struck by an object were the major causes for complete spinal cord damage. The neurological deficits caused by voluntary falls and accidental falls are quite different from each other. Thus accidental falls resulted in a higher incidence 
of cervical cord injuries than did voluntary falls. These findings accord with those of Girard (1980) who reported low cord lesions with better motor evolution in suicidal (voluntary) falls because of different heights of jump, body position and the protection from the legs when landing. There were no cases of SCI caused by gunshot wounds because people are not allowed to possess firearms in Taiwan.

The neurological deficits in the 15 cases caused by a stab injury were very characteristic, most of them being at the thoracic level, and the neurological deficits were related to the body height of the criminal, the type of weapon and the direction and force of penetration. About half of our cases $(58 \%)$ had complete cord damage (Table 4).

In Taiwan the pre-hospital care is not well organised, all the patients being sent to hospital by untrained personnel with improper technique, because knowledge of the first aid management of SCI is not known to the public. We realise that active participation of doctors who are interested in the management of SCI, especially in the pre-hospital care of these patients will reduce the number of patients with complete cord damage in the future. The mortality rate was 6.0 per cent, the majority of the deaths occurring in tetraplegics because of respiratory complications. Only a few paients died as a result of pressure sores or from renal failure (Table 5). The fact that the time of follow up in this study was very short (less than 6 months) may account for this specific pattern of death.

\section{Zusammenfassung}

Diese Untersuchung ueber Rueckenmarksverletzungen in Taipei Stadt in der Zeit vom Januar 1978 bis Dezember 1981 wurde durch eine Ueberpruefung der Krankenhaustabellen durchgefuehrt. Innerhalb dieser 4 Jahre wurden 560 akute Rueckenmarksverletzungen ( $\mathrm{SCI}=$ spinal cord injuries) in den 15 grossen Krankenhaeusern Taipeis aufgenommen. 123 davon kamen aus Taipei Stadt. Dies zeigt ein jaehrliches Vorkommen von SCI in Taipei von 14.6 auf eine Million Einwohner. Als Folge der Verletzung zeigten 118 Faelle paraparetische, 180 paraplegische, 117 quadriparetische und 145 quadriplegische Folgen. Das Durchschnitts - alter betrug 36 Jahre und 2 Monate. Ein Drittel der Kranken were zwischen 20 - 29 Jahre alt. Das Verhältnis von maennlichen zu weiblichen Kranken 4.9. Die Ursachen fuer SCI waren Verkehrsunfaelle $(44.5 \%)$, Ungluecksfaelle $\left(28.5^{\circ}{ }_{0}\right)$, Schlag durch fremde Objeket $\left(14 \cdot 6^{\circ}{ }_{0}\right)$ und Sportverletzungen $\left(3 \cdot 4^{\circ}{ }_{0}\right)$. Die Sterblichkeitsrate betrug $6^{\circ}{ }_{0}$. Die Haupttodesursache waren Atmungskomplikationen $58^{\circ}{ }_{0}$.

\section{Résumé}

Par la méthode de l'examen sur la courbe à l'hôspital, cette enquête des lésions de la moelle épinière à Taipei de Jan. 1978 au Dec. 1981 a été effectuée. Pendant ces quatre années, 560 cas avec la lésion de la moelle épinière (SCI) aiguë ont été admis à 15 grands hôspitaux à Taipei. Parmi eux 123 cas sont l'habitant de Taipei, révélant que l'incidence annuelle de SCI à Taipei est 14,6 le million de la population, par suite de l'enquête, 118 cas sont paraparetique, 180 cas sont paraplegique, 117 cas sont quadriparetique et 145 cas sont quadriplegique. La moyenne d'âge est 36 ans et 2 mois. Un tier d'entre eux est à l'âge de 20 à 29 ans. Le masculin et la féminin est dans la proportion de 4,9. Les causes de SCI sont l'accident de la circulation $\left(44,5^{\circ}{ }_{0}\right)$, la chute accidentelle $(28,5 \%)$, le coup d'objet $\left(14,6^{\circ}{ }_{0}\right)$ et la lésion des sports $\left(3,4^{\circ}{ }_{0}\right)$. Le taux de mortalité est $6,0^{\circ}{ }_{0}$. La complication respiratoire est la cause principale de mort, il a justifié de $58^{\circ}{ }_{0}$ de la mort.

\section{Acknowledgements}

This study is supported by grants from the National Health Administration and National Science Council, Republic of China (NSC-73-0412-B002-49). 


\section{References}

Fine PR, Kuhlemeier KV, Devivo MJ, et al. 1980 Spinal cord injury: an epidemiologic perspective. Paraplegia 17:237-250.

FRANKel HL, HANCOCK DO, Hyslop G, et al. 1969 The Value of postural reduction in the initial management of closed injuries of the spine with paraplegia and tetraplegia. Paraplegia 7:179-192.

Girard R, Minaire P, Castanier M, et al. 1980 Spinal cord injury by falls: comparison between suicidal ảnd accidental cases. Paraplegia 18:381-385.

Girard R, Boisson D, Depassio J, et al. 1983 The female paraplegic: a statistical survey. Paraplegia $21: 149-153$.

GJONE R, NORDLIE L 1979 Incidence of traumatic paraplegia and tetraplegia in Norway: a statistical survey of the years 1974 and 1975. Paraplegia 16:88-93.

KraUs JF, Franti CE, Riggins RS, et al. 1975 Incidence of traumatic spinal cord lesions. Journal of Chronic Diseases 28:471-492.

KRAUS JF 1980 Injury to the head and spinal cord. The epidemiological relevance of the medical literature published from 1960 to 1978. J. Neurosurg. 53:S3-S10.

KuHN W, ZACH GA, Kochlin PH, et al. 1983 Comparison of spinal cord injuries in females and in males, 1979-1981 Basle. Paraplegia 21:154-160.

Minaire P, Castanier M, Girard R, et al. 1978 Epidemiology of spinal cord injury in the Rhône-Alpes region, France, 1970-75. Paraplegia 16:76-87.

World Health Organization 1969 Manual of the International Statistical Classification of Disease, Injuries and Causes of Death, 8th ed., Geneva. 